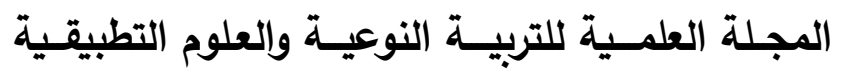

The Scientific Journal of Specific Education and Applied Sciences

\title{
Potential Ameliorative Effects of Corn Silk on \\ Hepatic Damage induced by Carbon tetrachloride in Experimental Rats
}

\author{
Tasneem Sobhy Fahmy \\ Nutrition and Food Science Department, Faculty of Home Economics, \\ Helwan University.
}

\begin{abstract}
This study was carried out to investigate the ameliorative effect of corn silk on hepatic damage in rats. Thirty-five albino rats of Sprague-Dawley strain were randomly distributed after the adaptation period into two main groups (7 of each), the first main group was kept on the basal diet as negative control (-ve), The rest of the animals $(n=28)$ were subcutaneously injected with a single dose of $\mathrm{CCl}_{4}$ for the induction of necrosis. After injection of $\mathrm{CCL}_{4}$, rats were divided into 4 subgroups. The first subgroup of rats was as a positive control group (+ve). The other subgroups were fed on the experimental diets containing different levels of corn silk 5\%, 7.5\% and $10 \%$, respectively. At the end of the experimental period (6 weeks) liver and kidney functions were determined. Also, antioxidants enzymes in addition MDA were determined. Histopathological examination for liver and kidneys were done. The results indicated that liver enzymes including ALT, AST, ALP in addition albumin, total and direct bilirubin were decreased in groups 3,4 and 5, respectively compared with the positive control group. Urea nitrogen and creatinine were significantly improved in all tested groups compared with the positive control one. Moreover, antioxidant enzymes (SOD and CAT) were significantly improved in all examined groups compared with the positive control group. However, serum MDA decreased significantly in tested groups which were treated with $5 \%, 7.5 \%$, and $10 \%$ corn silk when compared with the positive control group. It could be concluded that corn silk had a potential effect against hepatic damage therefore this
\end{abstract}


المجـلة العلمـية للتربيـة النوعيـة والعلوم التطبيقـية

The Scientific Journal of Specific Education and Applied Sciences

study recommends increasing dietary intake of corn silk could be beneficial for patients with hepatic damage.

Key words: Corn silk, liver enzymed, Hepatic Damage, Antioxidant Enzymes. 


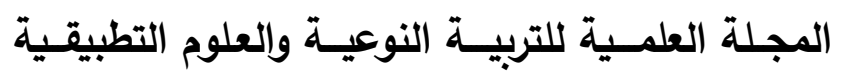

The Scientific Journal of Specific Education and Applied Sciences

\section{Introduction}

Corn silk (CS) is a yellow- to a light-brown-colored ingredient known for its effectiveness in the treatment of urinary infection and related diseases. In many countries it has been widely used as a treatment for diseases such as urinary stones, nephritis, liver diseases and diabetes and as a diuretic (So et al., 2017). Corn silk has maysin and has conducted physiological activity screening and efficacy assays on maysin. Maysin (C-glycosyl flavone) is synthesized along a branch of the flavonoid pathway in corn silk and is a host-plant resistance factor against corn earworm (Kim et al., 2014).

Corn silk (Maydis stigma) is a waste material from corn cultivation, available in abundance and have antioxidant, anti-tumor, anti-fatigue, and anti-fungal activities (Ebrahimzadeh et al., 2009 and $\mathrm{Hu}$ et al., 2010). In folk medicine, corn silk is used for the treatment of cystitis, edema, diabetes mellitus, and prostatitis . CS contains a great amount of phenolic compounds, such as flavonoids (maysin, apigmaysin, luteolin), anthocyanins (cyanidin, peonidin) (Kim et al., 2014), chlorogenic acid, and other biologically active substances, such saponins and allantoin (Ku et al., 2009). The antioxidant capacities of the CS extract have been implicated in human breast cancer cells (Tian et al 2013). In addition, oral ingestion of CS-extracted flavonoids showed antioxidant effects against oxidative stress under exhaustive exercise (Hu and Deng, 2011).

Nutrients present in the corn silk contains a higher amount of fibre (6g) and less in fat (0.36g) Sodium (mg) 720.27, Potassium (mg) 1079.08 (Bhuvaneshwari et al., 2017). Microwave dried corn silk contains high amount of total antioxidant activity .Some flavonoids or isoflavones were extracted from CS exhibited kinds of biological activities such as estrogenic, anti-oxidant activities, antiosteoporosis, anti-diabetes and anti-carcinogenic effects (Wan et al., 2014).

The liver is one of the important organs of the body which plays a major role in the metabolism of proteins, carbohydrates and 


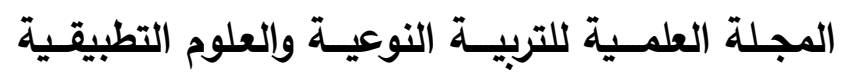

The Scientific Journal of Specific Education and Applied Sciences

lipids. It also has a lot of functions including detoxification, production of several coagulation factors, storage of glycogen, and growth factors hormones (Abd El-Ghany and Nanees, 2010). The liver regulates most chemical levels in the blood and excretes a product called bile. Bile helps to break down fats, preparing them for further digestion and absorption. All of the blood leaving the stomach and intestines passes through the liver. The liver processes this blood and breaks down, balances, and creates nutrients for the body to use (Way and Doherty, 2003).

Hepatic damage induced in rats by carbon tetrachloride was obvious macroscopically as well as microscopically in stained sections. Levels of AST, ALT, and ALP were also significantly raised. Adenosine and inosine effectively countered the damage when these were given before and during the period during which $\mathrm{CCl}_{4}$ produces the typical damage (Singh et al., 1992). Therefore, this study was conducted to ameliorative effects of CS on cronic liver disease in rats.

\section{Materials and methods}

Materials:

Carbon tetrachloride $\left(\mathrm{CCl}_{4}\right)$, cellulose, vitamin mixture, minerals, and the kits which were used for biochemical analysis were purchased from El-Gomhoria Company for Trading Drugs, Chemicals and Medical Requirements. CS was purchased from the local market.

Thirty-five albino rats of Sprague-Dawley strain weighing approximately $150 \pm 5 \mathrm{~g}$ were purchased from Helwan Farm for Experimental Animals, Cairo, Egypt.

\section{Methods:}

\section{Preparation of CS powder:}

Fresh CS was washed by using tap water and was dried using solar energy at the National Research Centre, Giza, Egypt in the sun for two days then grounded to get a fine powder. The sun rays enable the dried product to retain its nutrients as described by (Andritsos $\boldsymbol{e t}$ al., 2003). 


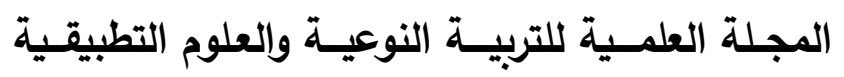

The Scientific Journal of Specific Education and Applied Sciences

\section{Experimental animal design}

\section{Preparation of basal diet:}

The basal diet was prepared according to Reeves et al. (1993). It consists of $20 \%$ protein, $10 \%$ sucrose, $4.7 \%$ corn oil, $2 \%$ choline chloride, $3.5 \%$ salt mixture, $1 \%$ vitamin mixture, and $5 \%$ fibers. The remainder was corn starch up to $100 \%$.

Animals were divided into two main groups $n=7$, once. The first main group $(n=7)$ was fed on the basal diet during the experimental period and used as a negative control group (-ve). The rest of the animals $(n=28)$ were subcutaneously injected with a single dose of $\mathrm{CCl}_{4}(2 \mathrm{ml} / \mathrm{kg}$ body weight/ day) for the induction of necrosis for a period of two weeks. This dosage was proved to be effective from the earlier report as stated by Seethalakshmi et al., 1982.

After injection of rats with $\mathrm{CCL}_{4}$, animals were divided into 4 subgroups as follows:

Subgroup (1) Rats with hepatic damage were fed on the basel diet as positive control group.

Subgroup (2) Rats with hepatic damage were fed on the basel diet supplemented with $5 \%$ CS powder.

Subgroup (3) Rats with hepatic damage were fed on the basel diet supplemented with $7.5 \%$ CS powder.

Subgroup (4) Rats with hepatic damage were fed on the basel diet supplemented with $10 \%$ CS powder.

At the end of the experiment (6weeks) all rats fasted overnight, lightly anesthetized under ether. Blood was withdrawn into clean dry centrifuge plastic tubes. Blood samples were centrifuged, and serum was obtained then stored at $-20^{\circ} \mathrm{C}$ in a clean well stopped vial until analysis.

\section{Chemical analysis:}

Phenolic compounds and antioxidant activity were measured according to the method of Brand et al., 1995. The liver enzyme alanine aminotransferase (ALT), Aspartate aminotransferase (AST), serum alkaline phosphatase, were determined according to Sherwin (1984), Young (1990), and Roy (1970), respectively. Serum albumin, total bilirubin and direct bilirubin was determined according to Young, (2001). Serum urea nitrogen, and creatinine concentration were determined by the 


\section{المجـلة العلمـية للتربيـة النوعيـة والعلوم التطبيقـية}

The Scientific Journal of Specific Education and Applied Sciences

method of Fossati et al., (1980), and Henry (1974), respectively. Serum MDA was determined according to Draper and Hadly (1990). Serum CAT activity, and serum SOD were measured according to Aebi (1984), and Nishikimi et al., (1972), respectively.

\section{Statistical analysis:}

The statistical analysis was carried out by using SPSS, PC statistical software (Verion 18.0 SPSS Inc., Chieago, USA) using the Dunk 'test multiple range post-hoc test. Data were analyzed by oneway analysis variance (ANOVA). The values were considered significantly different at $\mathrm{P}<0.05$ (Snedecor and Cochran, 1980).

\section{$\underline{\text { Results and Discussion }}$}

\section{Determination of total phenolic content in corn silk.}

The total phenolic content of corn silk determined by agilent1260 infinity HPLC Series (Agilent, USA), equipped with Quaternary pump,aKinetex ${ }^{\circledR} 5 \backslash \mathrm{Jm}$ EVO C18 $100 \mathrm{~mm}$ x $4.6 \mathrm{~mm}$, (Phnomenex, USA), operated at 300 Co The separation is achieved using a ternary linear elution gradient with (A) HPLC grade water $002 \% . \mathrm{H} 3 \mathrm{P} 04(\mathrm{v} / \mathrm{v}),(8)$ methanol and (C) acetonitrile. The injected volume was 20 \J .Detection:VWD detector set at $284 \mathrm{nrn}$ (Brand, et al., 1995).

The total phenolic content of corn silk are presented in Table (1). The results indicate that corn silk contained mild amount of myricetin acid, benzoic acid, Salicylic acid, Neringein , Kampherol, respectively. The Ellagic recorded the largest amount of phenolic content in corn silk with mean value $417.11 \mathrm{mg} / \mathrm{kg}$.

Table (1): Total phenolic content of corn silk

\begin{tabular}{|c|c|}
\hline Phenolic Compounds & Corn Silk_(mg / kg) \\
\hline Syringic acid & 1.50 \\
\hline Vanillic acid & 2.07 \\
\hline p- Coumaric acid & 2.25 \\
\hline Quercetin & 2.73 \\
\hline Cinnamic acid & 3.62 \\
\hline Rutin & 4.14 \\
\hline
\end{tabular}




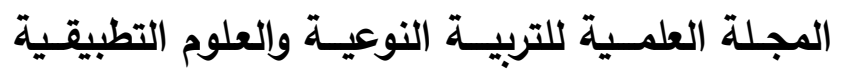

The Scientific Journal of Specific Education and Applied Sciences

\begin{tabular}{|c|c|}
\hline Chlorogenic & 4.30 \\
\hline Ferulic acid & 4.83 \\
\hline Caffeic acid & 5.01 \\
\hline Caffeine & 5.14 \\
\hline Myricetin acid & 16.81 \\
\hline Benzoic acid & 23.84 \\
\hline Salicylic acid & 34.73 \\
\hline Neringein & 61.87 \\
\hline Kampherol & 75.54 \\
\hline Ellagic & 417.11 \\
\hline Quinol & -- \\
\hline Gallic acid & -- \\
\hline Pyrogallol & -- \\
\hline Catechol & -- \\
\hline
\end{tabular}

\section{The Antioxidant activity of corn silk}

Five grame from corn silk was prepared in $50 \mathrm{ml}$ methanol. An aliquot of extract was added to DPPH radical (100 IJI, $0.2 \mathrm{mM}$ ) dissolved in methanol. The mixture was stirred and left to stand for $15 \mathrm{~min}$ in dark. Then the absorbance was measured at $517 \mathrm{~nm}$ against a blank. Percentage scavenging effect was calculated as: [(AO - A 1) $I \mathrm{AO}] \mathrm{x} 100$ where: $\mathrm{AO}$ is the absorbance of the control (without sample) and A 1 is the absorbance in the presence of the sample (Brand, et al., 1995).

The data in table (2) shown the result of radical scavenging activity for corn silk which recorded high antioxidant activity $84.01 \%$ in $5 \%$ concentration.

Table (2): The Antioxidant activity of corn silk

\begin{tabular}{|l|l|l|l|l|}
\hline SN & \multicolumn{4}{|c|}{ \% DPPH Radical-Scavenging Activity } \\
\hline & $0.5 \%$ & $1.0 \%$ & $2.5 \%$ & $5 \%$ \\
\hline $\begin{array}{l}\text { Corn } \\
\text { Silk }\end{array}$ & 20.30 & 40.99 & 60.11 & 84.01 \\
\hline
\end{tabular}




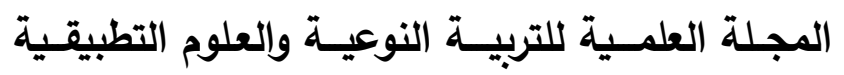

The Scientific Journal of Specific Education and Applied Sciences

\section{Effect of CS at different levels on liver enzymes on rats suffering from liver damage}

Results in Table (3) showed the effect of CS powder on the serum activity of alanine aminotransferase (ALT). Results showed that ALT was increased significantly in rats suffering from hepatic damage (positive control group) with a mean value of $142.33 \pm 23.05$ U/L compared with the negative control group with a mean value of $35.33 \pm 2.84 \mathrm{U} / \mathrm{L}$. Results revealed that rats were fed on CS powder in the diet showed a reduction in the serum activity of ALT at any levels of intake when compared with the positive control group. Finally, group 5 is considered the best group in reducing the increase of ALT concentration.

Results in Table (3) showed the effect of CS powder on serum activity of aspartate aminotransferase (AST). Data indicated that AST activity was increased significantly in rats suffering from hepatic damage (positive control group) with a mean value of $181.66 \pm 3.75 \mathrm{U} / \mathrm{L}$ compared with the negative control group with a mean value of $36.00 \pm 2.30 \mathrm{U} / \mathrm{L}$. Results revealed that when rats were fed on CS powder in the diet showed a reduction in the serum activity of AST at any levels of intake when compared with the positive control group. The best results were seen in group 5.

Concerning alkaline phosphatase (ALP) concentration in table (3), data indicated that when rats had hepatic damage (positive control) showed a significant increase of their serum ALP level (192.00 $\pm 3.51 \mathrm{U} / \mathrm{L})$ compared with the normal rats fed on the basal diet (negative control) with a mean value of $168.66 \pm 7.31 \mathrm{U} / \mathrm{L}$. Furthermore, when rats were fed on CS powder in the diet showed a significant decrease in the serum activity of ALP at any levels of intake when compared with the positive control group.

The serum enzyme activities of ALT and AST are widely used as indicators of tissue injury, and the concentrations of these enzymes may increase markedly after injury to a specific tissue or organ, such as hepatic injury. No significant increases in ALT and AST activity were observed in the corn silk treated rats in this study, indicating that the CS intake levels were safe (So et al., 2017).

Flavonoid is the most active compound on corn silk which evidently has high antioxidant level and uppermost DPPH scavenging activity so, the activity of corn silk infusion on liver 


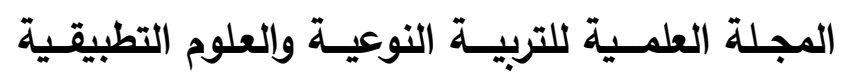

The Scientific Journal of Specific Education and Applied Sciences

enzyme alteration may be connected to its active compound in addition flavonoid can neutralize free radicals, $\mathrm{CCl} 4$ in this regard, since it has an aromatic ring as an electron donor that stabilize the free radicals ion (Pham et al., 2008).

This study is in the same line with both Abirami et al., (2015) and Enas et al., (2020) whose recommended that treatment with CS led to improvement of liver tissue which can be attributed to the antioxidant activity of corn silk due to its total phenolic and flavonoids content. Histopathological findings CS protected the hepatic tissue against acetaminophen through its antioxidant activity.

Alkaline Phosphatases (ALP) are homodimer enzymes that can be found in several tissues but are abundant in liver . It is a canicular enzyme that plays a role in bile production with its elevation level may indicate the liver problem, cholestasis . Carbon tetrachloride can elucidate liver damage with the mechanism of action such as fatty degeneration, fibrosis, hepatocellular death, and carcinogenicity that alter the biomarker level of the liver, increasing ALP level (Ebrahimzadeh et al., 2009).

Table (3): Effect of CS at different levels on liver enzymes on rats suffering from liver damage

\begin{tabular}{|c|c|c|c|}
\hline Parameters & $\begin{array}{c}\text { ALT } \\
\text { Groups }\end{array}$ & $\begin{array}{c}\text { AST } \\
(\mathbf{U} / \mathbf{L})\end{array}$ & $\begin{array}{c}\text { ALP } \\
(\mathbf{U} / \mathbf{L})\end{array}$ \\
\hline G 1 (- Ve control) & $35.33 \pm 2.84^{\mathrm{d}}$ & $36.00 \pm 2.30^{\mathrm{d}}$ & $168.66 \pm 7.31^{\mathrm{b}}$ \\
\hline $\begin{array}{c}\text { G 2 (+Ve control) } \\
23.05^{\mathrm{a}}\end{array}$ & $181.66 \pm 3.75^{\mathrm{a}}$ & $192.00 \pm 3.51^{\mathrm{a}}$ \\
\hline $\begin{array}{c}\text { G 3 ( 5\% corn } \\
\text { silk powder) }\end{array}$ & $61.66 \pm 7.26^{\mathrm{c}}$ & $71.66 \pm 6.00^{\mathrm{bc}}$ & $171.00 \pm 3.60^{\mathrm{b}}$ \\
\hline $\begin{array}{c}\text { G 4 ( 7.5\% corn } \\
\text { silk powder) }\end{array}$ & $80.66 \pm 2.33^{\mathrm{b}}$ & $77.35 \pm 3.17^{\mathrm{b}}$ & $174.00 \pm 8.08^{\mathrm{b}}$ \\
\hline $\begin{array}{c}\text { G 5 ( 10\% corn } \\
\text { silk powder) }\end{array}$ & $59.33 \pm 6.35^{\mathrm{c}}$ & $67.00 \pm 1.52^{\mathrm{c}}$ & $167.00 \pm 6.50^{\mathrm{b}}$ \\
\hline
\end{tabular}

Each value represents the mean value \pm SD. Mean's values in the same column sharing the different superscript letters are significant different at $\mathrm{P}$ $\leq 0.05$. 


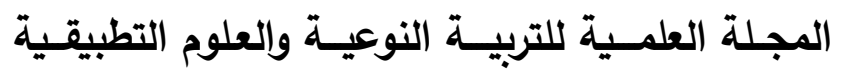

The Scientific Journal of Specific Education and Applied Sciences

\section{Ameliorative effects of CS at different levels on serum concentrations of total bilirubin, direct bilirubin and albumin of rats suffering from liver damage}

Results in Table (4) showed the effect of CS powder on serum concentrations of total bilirubin. Results showed that total bilirubin was increased significantly in rats suffering from hepatic damage (positive control group) with a mean value of $0.52 \pm 0.01 \mathrm{mg} / \mathrm{dl}$ compared with the negative control group with a mean value of $0.26 \pm 0.03 \mathrm{mg} / \mathrm{dl}$. Results clarified when rats were fed on CS powder in the diet at any levels of intake total bilirubin decreased significantly when compared with the positive control group. However, there are no significant changes in groups 3, 4 and 5, respectively.

Results in Table (4) clarified the effect of CS powder on serum concentrations of total bilirubin and direct bilirubin. Data indicated that total bilirubin was increased significantly in rats suffering from hepatic damage (positive control group) with a mean value of $0.18 \pm 0.01 \mathrm{mg} / \mathrm{dl}$ compared with the negative control group with a mean value of $0.10 \pm 0 \mathrm{mg} / \mathrm{dl}$. Results revealed that when rats were fed on CS powder in the diet showed a reduction in the serum concentration of direct bilirubin at any levels of intake when compared with the positive control group. However, There are no appreciable difference between groups 3,4 and 5, respectively and negative control group.

In connection with serum concentration of albumin in table (4), data indicated that when rats had hepatic damage (positive control) showed a significant decrease of their serum albumin (3.55 $\pm 1.19 \mathrm{~g} / \mathrm{dl}$ ) compared with the normal rats fed on the basal diet (negative control) with a mean value of $5.45 \pm 0.27 \mathrm{~g} / \mathrm{dl}$. However, when rats were fed on CS powder in the diet showed a significant increase in serum albumin at any levels of intake when compared with the positive control group.

This result demonstrated that there is the enhancment of serum concentration of total bilirubin, direct bilirubin and albumin, respectively CS led to improvement of liver tissue when rats fed on a diet supplemented with CS powder this improvement can be attributed to the antioxidant activity of corn silk due to its total 


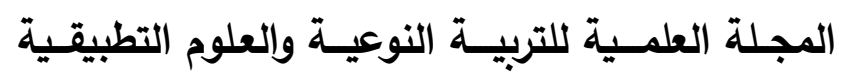

The Scientific Journal of Specific Education and Applied Sciences

phenolic and flavonoids content (Tanideh et al., 2018). many constituents and flavonoids that quenching of free radicals and has antioxidant effects of these compounds have been established. In addition, CS contains proteins, sugars, vitamins (especially riboflavin), minerals. Corn silk is very well known for its antiinflammatory properties. Traditional medicine followers are of the view that it can be used in reducing the pain caused by inflammatory ailments like gout and arthritis.

Table (4): Ameliorative effects of CS at different levels on serum concentrations of total bilirubin, direct bilirubin and albumin of rats suffering from liver damage

\begin{tabular}{|c|c|c|c|}
\hline Groups Parameters & $\begin{array}{c}\text { Total } \\
\text { Bilirubin } \\
(\mathrm{mg} / \mathrm{dl})\end{array}$ & $\begin{array}{c}\text { Direct } \\
\text { Bilirubin } \\
\text { (mg/dl) }\end{array}$ & $\begin{array}{l}\text { Albumin } \\
(\mathrm{g} / \mathrm{dl})\end{array}$ \\
\hline G 1 (- Ve control) & $0.26 \pm 0.03^{c}$ & $0.10 \pm 0^{\mathrm{b}}$ & $5.45 \pm 0.27^{\mathrm{a}}$ \\
\hline G 2 (+Ve control $)$ & $0.52 \pm 0.01^{\mathrm{a}}$ & $0.18 \pm 0.01^{\mathrm{a}}$ & $3.55 \pm 1.19^{c}$ \\
\hline $\begin{array}{c}\text { G } 3 \text { ( } 5 \% \text { corn silk } \\
\text { powder })\end{array}$ & $0.40 \pm 0.01^{\mathrm{b}}$ & $\begin{array}{l}0.11 \pm \\
0.005^{\mathrm{b}}\end{array}$ & $5.32 \pm 0.18^{\mathrm{a}}$ \\
\hline $\begin{array}{c}\text { G } 4\left(\begin{array}{c}7.5 \% \text { corn silk } \\
\text { powder })\end{array}\right.\end{array}$ & $0.40 \pm 0.005^{\mathrm{b}}$ & $0.10 \pm 0.005^{\mathrm{b}}$ & $4.99 \pm 1.26^{\mathrm{b}}$ \\
\hline $\begin{array}{c}\text { G } 5 \text { ( } 10 \% \text { corn silk } \\
\text { powder })\end{array}$ & $0.40 \pm \frac{\mathrm{b}}{0.008}$ & $0.12 \pm 0.005^{b}$ & $4.00 \pm 0.19^{\mathrm{bc}}$ \\
\hline
\end{tabular}

Each value represents the mean value \pm SD. Mean's values in the same column sharing the different superscript letters are significant different at $\mathrm{P}$ $\leq 0.05$.

\section{Ameliorative effects of CS at different levels on serum concentrations on urea nitrogen and creatinine of rats suffering from liver damage}

Table (5) showed the effect of CS powder on kidney functions (urea nitrogen and creatinine concentration in serum). When rats were injected with $\mathrm{CCl}_{4}$ the concentration of serum levels of urea nitrogen was significantly increased with a mean value of $54.00 \pm 2.08$ 


\section{المجـلة العلمـية للتربيـة النوعيـة والعلوم التطبيقـية}

\section{The Scientific Journal of Specific Education and Applied Sciences}

$\mathrm{mg} / \mathrm{dl}$ compared with the negative control group $(37.33 \pm 2.66 \mathrm{mg} / \mathrm{dl})$. While the groups of rats fed on CS powder at any level of intake showed a significant decrease in serum levels of urea nitrogen in addition group (5) considered the best value of serum urea nitrogen concentration.

The data in the same table clarified that the positive control group with hepatic damage had increased in the concentration of creatinine level with a mean value of $0.75 \pm 0.04 \mathrm{mg} / \mathrm{dl}$ compared with the negative control group $(0.66 \pm 0.03 \mathrm{mg} / \mathrm{dl})$. Groups of rats with hepatic damage which were fed on CS powder at any levels of intake showed a reduction in the concentration of serum levels of creatinine compared with the positive control group. The best level was shown in groups 3 and 5 and consider better than the negative control group.

Serum urea nitrogen and creatinine levels are used in the assessment of renal problems. Urea nitrogen and creatinine levels were measured to assess renal toxicity. The increase in creatinine in the positive control group recorded in this work might be due to impaired kidney function by the used toxicity. This view was supported by Ahmed et al., (2006) who showed that an elevation of urea nitrogen and creatinine level in the blood is an indicator of impaired kidney function.

These results was the same line with Sukandar et al., 2013 who demonstrated that corn silk extract improvement kidney functions by increasing the urine output, which can help remove the toxins and wastes out, hence reducing creatinine level. Also, CS extract helps remove the excess fluid out, which can help relieve the swelling. High blood pressure, being the most prominent symptom, is reduced with the help of corn silk extract .Corn silk containing chemicals that work as diuretics, and can also helpful in reducing inflammations and kidney problems (Miriam et al., 2015). 


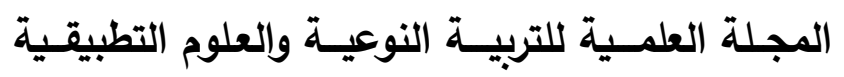

The Scientific Journal of Specific Education and Applied Sciences

Table (5): Ameliorative effects of CS at different levels on serum concentrations on urea nitrogen and creatinine of rats suffering from liver damage

\begin{tabular}{|c|c|c|}
\hline $\begin{array}{ll}\text { Groups } & \text { Parameters }\end{array}$ & $\begin{array}{l}\text { Urea Nitrogen } \\
(\mathrm{mg} / \mathrm{dl})\end{array}$ & $\begin{array}{c}\text { Creatinine } \\
(m g / d l)\end{array}$ \\
\hline G 1 (- Ve control) & $37.33 \pm 2.66^{\mathrm{bc}}$ & $0.66 \pm 0.03^{\mathrm{b}}$ \\
\hline G 2 (+Ve control) & $54.00 \pm 2.08^{\mathrm{a}}$ & $0.75 \pm 0.04^{\mathrm{a}}$ \\
\hline G 3 ( $5 \%$ corn silk powder) & $42.33 \pm 1.85^{\mathrm{b}}$ & $0.65 \pm 0.02^{\mathrm{b}}$ \\
\hline $\begin{array}{c}\text { G } 4 \text { ( } 7.5 \% \text { corn silk } \\
\text { powder })\end{array}$ & $44.00 \pm 2.08^{\mathrm{b}}$ & $0.70 \pm 0.05^{\mathrm{ab}}$ \\
\hline $\begin{array}{c}\text { G } 5 \text { ( } 10 \% \text { corn silk } \\
\text { powder })\end{array}$ & $34.33 \pm 2.84^{c}$ & $0.65 \pm 0.02^{\mathrm{b}}$ \\
\hline
\end{tabular}

Each value represents the mean value \pm SD. Mean's values in the same column sharing the different superscript letters are significant different at $\mathrm{P} \leq 0.05$.

\section{Ameliorative effects of CS at different levels on serum concentrations of antioxidant enzymes (SOD and CAT) in addition MDA of rats suffering from liver damage}

Table (6) showed the effect of corn silk on antioxidant activity such as SOD, CAT in a addition to Malondialdehyde. Results showed that there was a significant decrease in serum SOD and CAT in the positive control group with a man value $22.71 \pm 0.91 \mathrm{nmol} / \mathrm{min} / \mathrm{mg}$ protein and $1.26 \pm 0.12 \mathrm{U} / \mathrm{mg}$ ), respectively when compared with the negative control group $(26.68 \pm 1.73 \mathrm{nmol} / \mathrm{min} / \mathrm{mg}$ protein and $1.45 \pm 0.07 \mathrm{U} / \mathrm{mg})$. However, serum SOD and CAT increased significantly $(P<0.05)$ in groups 3 , 4 and 5 when compared with the positive control group. Moreover, the best value of SOD as noted in the group (5). However, the best value of CAT as noted in the group (4). On the other hand, results showed that there was an increase of MDA significantly in the positive control group when compared to the negative control group 


\section{المجـلة العلمـية للتربيـة النوعيـة والعلوم التطبيقـية}

\section{The Scientific Journal of Specific Education and Applied Sciences}

with a mean value of $42.01 \pm 2.46 \mu \mathrm{mol} / \mathrm{dL}$ and $29.25 \pm 2.22 \mu \mathrm{mol} / \mathrm{dL}$, respectively. Serum MDA in groups 3, 4 and 5 groups were decreased significantly $(P<0.05)$ when compared with the positive control group. Moreover, the best value of MDA was noted in the group (5).

SOD is considered a basel line of defense against the potentially cytotoxic O2 - free radicals that cause oxidative stress (Mallikarjuna et al., 2008). Superoxide dismutase gives $\mathrm{O} 2$ - to the more stable hydrogen peroxide $(\mathrm{H} 2 \mathrm{O} 2)$, which converted enzymatically into $\mathrm{H} 2 \mathrm{O}$ by catalase and glutathione peroxidase (Czako'et al., 2007).

Table (6) showing decreasing in MDA level on rats with hepatic damage and feeding on a diet supplemented with corn silk compared with the positive control group which reflects the high amount of antioxidant compounds like polyphenols, phenolic acids and flavonoids scavenge free radicals such as peroxide, hydroperoxide or lipid peroxyl and thus decreased the oxidative mechanisms that lead to degenerative diseases (Bouzid et al., 2015).

Biomarkers to evaluate the antioxidant capacity include SOD, CAT and the total antioxidant capacity (TAC) recording to Finsterer, (2012). This study is in the same line with $\mathbf{H u}$ and Deng, (2011) who reported that corn silk effectively increases antioxidant enzyme levels such as SOD and CAT.

Corn silk is a rich natural source of phytosterols, proteins, polyunsaturated fatty acids, antioxidant vitamins, carotenoids and tocopherols, and various elements, due to these components are attributed to providing many health benefits (Miriam et al., 2015).

Another study defined the antioxidant properties of corn silk was connected to diminishing level of ALT and augmenting level of GSH . Flavonoid is one of the active compounds on corn silk which evidently has great antioxidant level and uppermost DPPH scavenging activity . Based on those previous studies, the activity of corn silk infusion on enzyme alteration may be connected to its active compound and a flavonoid compound. Flavonoid can 


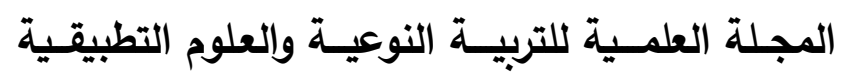

The Scientific Journal of Specific Education and Applied Sciences

neutralize free radicals, $\mathrm{CCl}_{4}$ in this regard, since it has an aromatic ring as an electron donor that stabilize the free radicals ion (Pham et al., 2008).

In conclusion, in this study we conveyed the hepatic damage caused by $\mathrm{CCl}_{4}$ which is signified by liver function tests elevations, alterations in antioxidant activities, changes of liver tissue histopathological findings. However, CS powder protected the hepatic tissue against $\mathrm{CCl}_{4}$ through its antioxidant activity and flavonids content.

Table (6): Ameliorative effects of CS at different levels on serum concentrations of antioxidant enzymes (SOD \& CAT) of rats suffering from liver damage

\begin{tabular}{|c|c|c|c|}
\hline Groups & $\begin{array}{c}\text { SOD } \\
\text { (U/mg } \\
\text { protein) }\end{array}$ & $\begin{array}{c}\text { CAT } \\
\left(\begin{array}{c}\text { nmol/min/mg } \\
\text { protein })\end{array}\right.\end{array}$ & $\begin{array}{c}\text { MDA } \\
(\mu \mathrm{mol} / \mathrm{dL})\end{array}$ \\
\hline $\begin{array}{l}\text { G } 1 \text { (- Ve } \\
\text { control) }\end{array}$ & $\underset{\mathrm{ab}}{26.68 \pm 1.73}$ & $1.45 \pm 0.07^{b}$ & $29.25 \pm 2.22^{\mathrm{b}}$ \\
\hline $\begin{array}{l}\text { G } 2(+\mathrm{Ve} \\
\text { control })\end{array}$ & $\begin{array}{c}22.71 \pm 0.91 \\
\mathrm{~b}\end{array}$ & $1.26 \pm 0.12^{\mathrm{c}}$ & $42.01 \pm 2.46^{\mathrm{a}}$ \\
\hline $\begin{array}{c}\text { G } 3 \text { ( 5\% corn } \\
\text { silk } \\
\text { powder }) \\
\end{array}$ & $\underset{\mathrm{a}}{29.40 \pm 0.65}$ & $1.87 \pm 0.19^{b}$ & $\underset{\mathrm{c}}{26.12 \pm 1.05}$ \\
\hline $\begin{aligned} & \mathbf{G ~} 4(7.5 \% \\
& \text { corn silk } \\
&\text { powder })\end{aligned}$ & $\begin{array}{c}27.60 \pm 0.56 \\
\mathrm{ab}\end{array}$ & $2.52 \pm 0.061^{\mathrm{a}}$ & $20.66 \pm 2.05^{\mathrm{d}}$ \\
\hline $\begin{array}{r}\text { G } 5 \text { ( } 10 \% \\
\text { corn silk } \\
\text { powder })\end{array}$ & $30.40 \pm 0.58^{\mathrm{a}}$ & $2.02 \pm 0.05 b^{\mathrm{ab}}$ & $25.88 \pm 2.44^{\mathrm{c}}$ \\
\hline
\end{tabular}

Each value represents the mean value \pm SD. Mean's values in the same column sharing the different superscript letters are significant different at $\mathrm{P}$ $\leq 0.05$. 


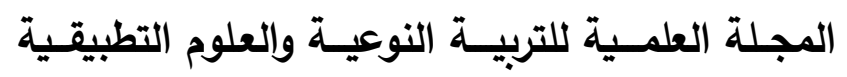

The Scientific Journal of Specific Education and Applied Sciences

\section{Histobathological Examinations:}

Microscopically, the liver of rats from group 1 revealed the normal histological structure of the hepatic lobule (Pho. 1 ). On the other hand, the liver of rats from group 2 showed focal hepatocellular necrosis associated with mononuclear inflammatory cells infiltration (Pho. 2). However, the liver of rats from group 3 revealed slight cytoplasmic vacuolization of hepatocytes (Pho.3) . Moreover, the liver from group 4 showed slight congestion of hepatic sinusoids (Pho.4). Examined sections from group 5 showed Kupffer cells activation (Pho.5).

Microscopical examination of the kidneys of rats from group 1 revealed the normal histological structure of renal tissue (Pho.6 ). However, Kidneys of rats from group 2 showed vacuolization of epithelial lining renal tubules (Pho. 7). Meanwhile, sections from group 3, 4 and 5 revealed no histopathological alterations (Pho. 8, 9 and 10).

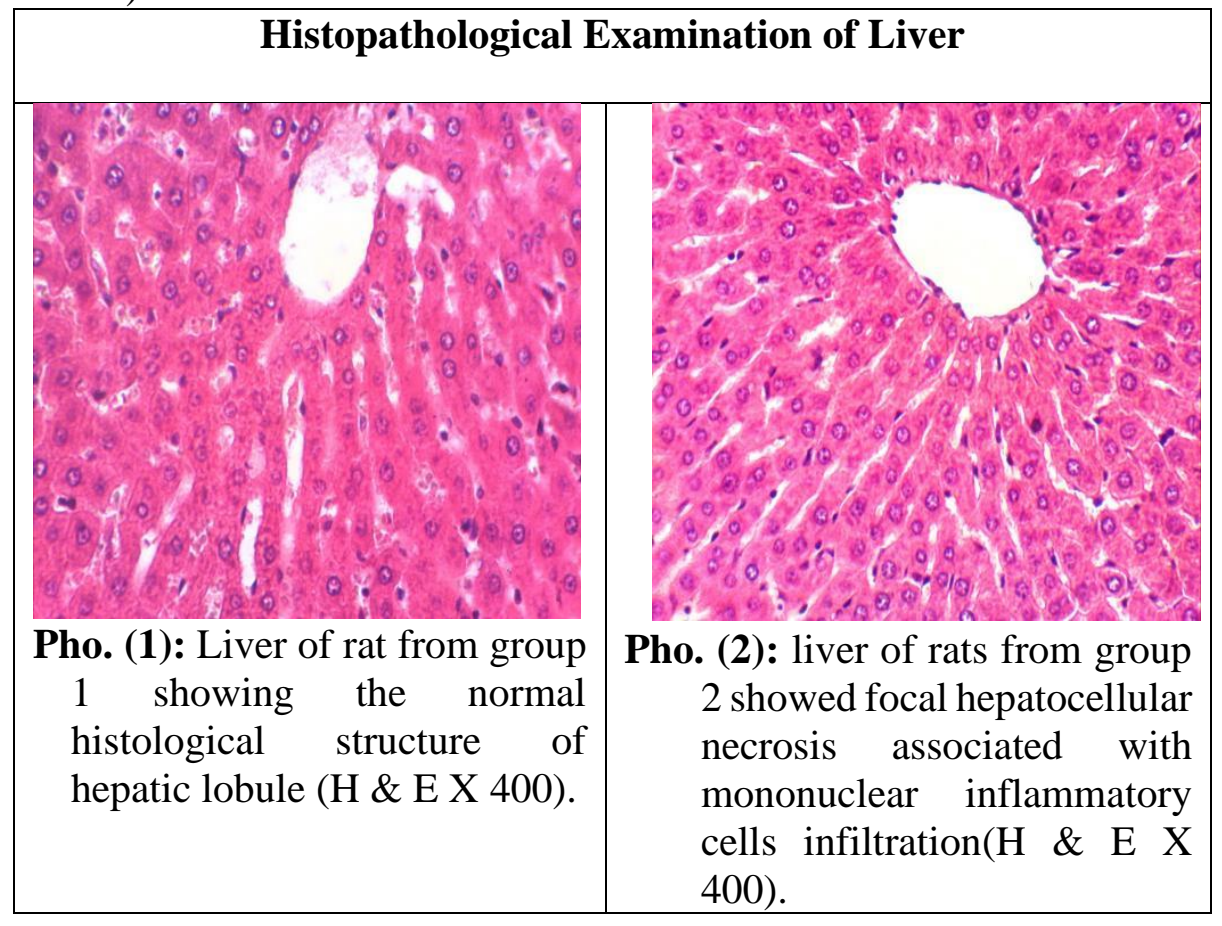




\section{المجـلة العلمـية للتربيـة النوعيـة والعلوم التطبيقـية}

\section{The Scientific Journal of Specific Education and Applied Sciences}

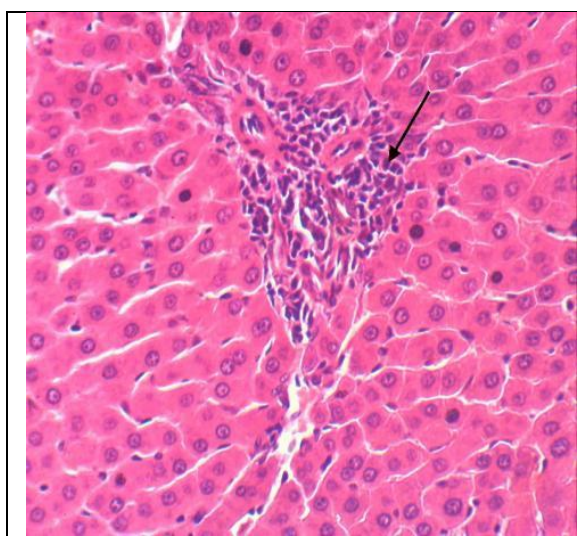

Pho. (3): Liver of rat from group 3 showing portal infiltration with few inflammatory cells (H \& E X 400).

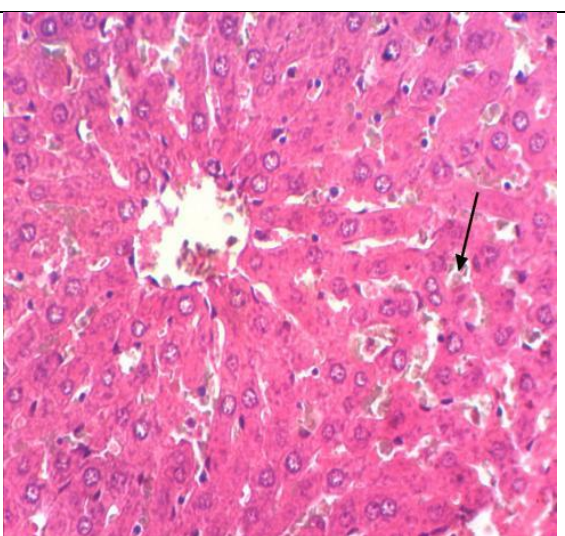

Pho. (4): Liver of rat from group 4 showing slight congestion of hepatic sinusoids $(\mathrm{H} \& \mathrm{E} \mathrm{X}$ 400).

Pho. (5): Liver of rat from group 5 showing Kupffer cells activation (H \& E X 400).

\section{Histopathological Examination of Kidneys}




\section{المجـلة العلمـية للتربيـة النوعيـة والعلوم التطبيقـية}

\section{The Scientific Journal of Specific Education and Applied Sciences}

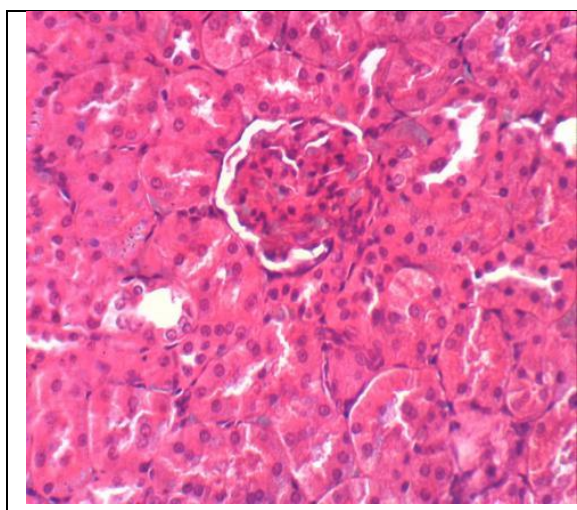

Pho. (6): Kidney of rat from group 1 showing the normal histological structure of renal tissue

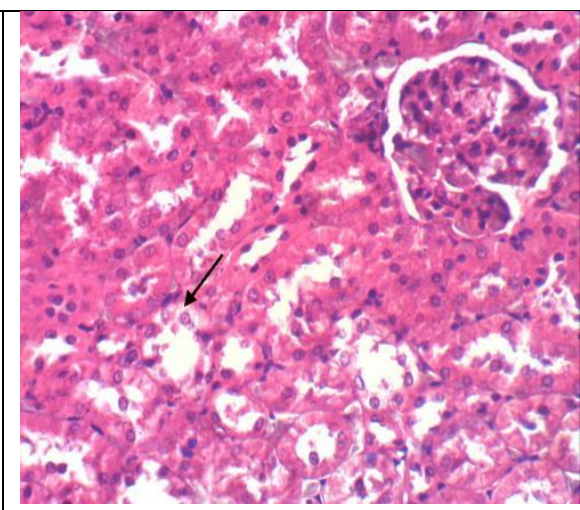

Pho. (7): Kidney of rat from group 2 showing vacuolization of epithelial lining renal tubules $(\mathrm{H} \& \mathrm{E} X$ 400).

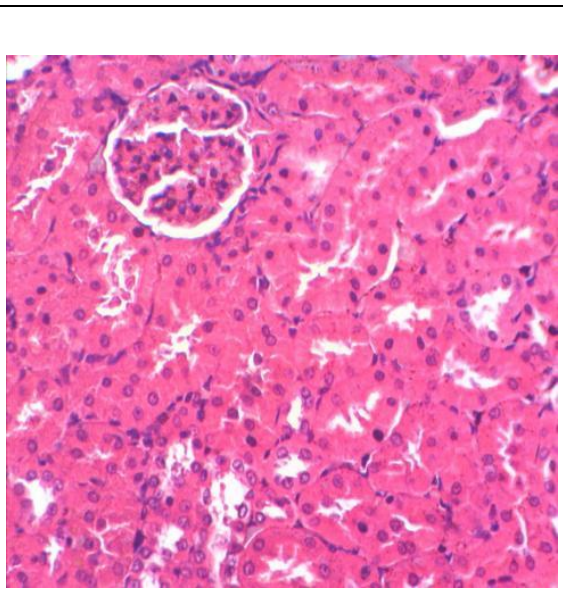

Pho. (8): Kidney of rat from group 3 showing no histopathological alterations.

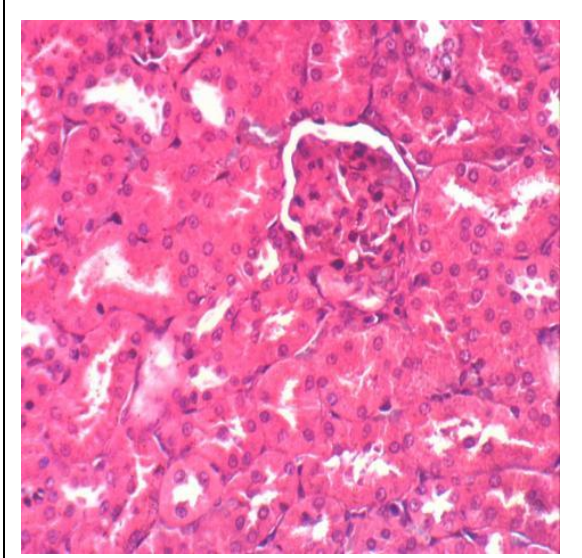

Pho. (9): Kidney of rat from group 4 showing no histopathological alterations. 
المجـلة العلمـية للتربيـة النوعيـة والعلوم التطبيقـية

The Scientific Journal of Specific Education and Applied Sciences

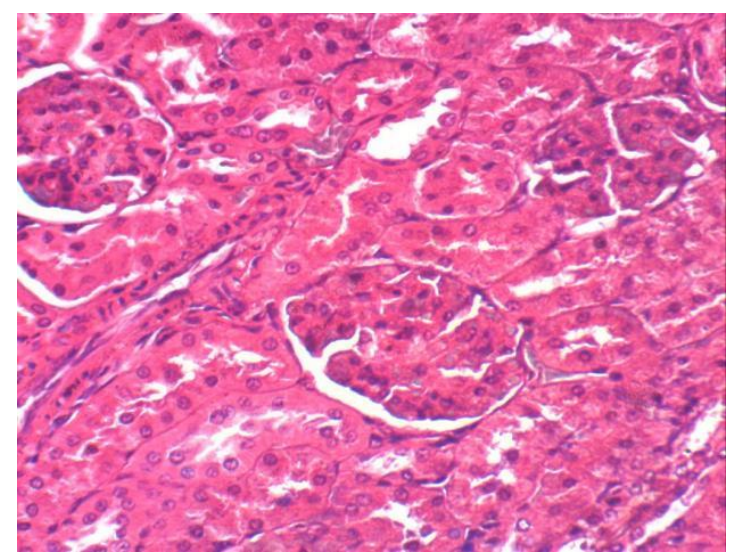

Pho. (10) : Kidney of rat from group 5 showing no histopathological alterations. 


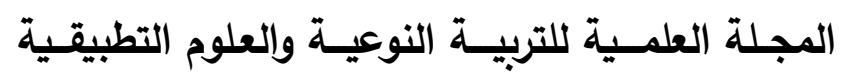

The Scientific Journal of Specific Education and Applied Sciences

\section{References}

Abd El-Ghany, M. and Nanees, Y. (2010): Effect of marjoram leaves on injured liver in experimental rats. Journal of Report and Opinion, 2(12): 181-191.

Abirami, A., Nagarani, G., Siddhuraju, P., (2015): Hepatoprotective effect of leaf extracts from Citrus hystrix and C. maxima against paracetamol induced liver injury in rats. Food. Sci. Hum. Well. 4 (1), 35-41.

Aebi, H. (1984): Catalase in vitro. In: Methods of Enzymology; 105: 121-126.

Ahmed, M.; Ambali, A. and Baba, S. (2006): Hematological and biochemical responses of Balami sheep to experimental Fasciola gigantica infection. Journal of Food Agriculture and Environment, 4(2): 71-74.

Andritsos, N., Dalampakis, P. and Kolios, N. (2003): Use of geothermal energy for tomto drying .Bulletin, 70(4): 9-13.

Bhuvaneshwari, K., FSMD, P. and Sivakami, S. (2017): Analysis of Nutrients and Phytochemicals content in Corn Silk(Zea. Mays). International Journal of Science and Research (IJSR). 6; (1).

Bouzid, M., Hammouda, O., Matran, R. and Robin, S. (2015): influence of physical fitness on antioxidant activity and malondialdehyde level in healthy older adults. Appl Physiol Nutr Metab; 40(6):582-9

Brand, W., Cuvelier, M. and Berset, C. (1995): Use of a freeradical method to evaluate antioxidant activity. LWT Food Sci. Techno. 28; 25-30.

Czako, L., Szabolcs, A., Vajda, A., Csati S., Venglovecz, V., Rakonczay, Z., Hegyi, P., Tiszlavicz, L., ' Csont, T., Posa, A., Berk' o A., Varga C., Ilona S., Boros I., Lonovics J. (2007): Hyperlipidemia induced ' by a cholesterol-rich diet aggravates necrotizing pancreatitis in rats. Eur J Pharmacol; 572:74-81.

Draper, H. and Hadley, M., (1990): Malondialdehyde determination as index of lipid peroxidation. Methods Enzymol. 186, 421-431.

Ebrahimzadeh, M., Pourmorad, F. and Hafezi, S. (2009): Antioxidant activities of Iranian corn silk. Turkish J Biol. 32:4349. 


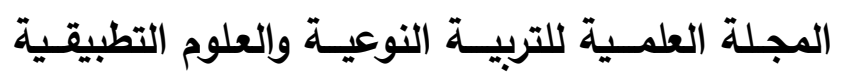

The Scientific Journal of Specific Education and Applied Sciences

Enas, W., Mohamed, A., Ahmed, M., Enas, T. and Sahar, O. (2020): Corn Silk Extract attenuates Acetaminophen-induced Hepatotoxicity in Rats. Damanhour Journal of Veterinary Sciences 4 (1), 11-14.

Fossati, P.; Prencipe, L. and Berti, G. (1980) : Enzymatic colorimetric method of determination of urea in serum .Clin .Chem.6(18) 499-502.

Finsterer, J. (2012): Biomarkers of peripheral muscle fatigue during exercise. BMC Musculoskelet Disord ; 13: 218.

Hamza, R. , El shahat, A. and Mekawey, H. (2013) : Hypoglycemic and Hypolipidemic Effect of Gamma-Irradiated Corn Silk on Male Albino Rats. Arab Journal of Nuclear S cience and Applications, 46(4), (252-259).

Henry, R. (1974): Creatinine measurement with colorimetric method. In clinical Chem., Principles and technics. Second edition, Haper and Row puplishers. hepatocytes. Cancer Lett, 97: 61-67.

Hu, Q. and Deng, Z. (2011): Protective effects of flavonoids from corn silk on oxidative stress induced by exhaustive exercise in mice. Afr. J. Biotechnol. ;10:3163-3167.

Hu, Q., Zhang, L., Li, Y., Ding, Y. and Li, F. (2010): Purification and anti-fatigue activity of flavonoids from corn silk. International Journal of Physical Sciences; 5(4); 321-326.

Kim, S., Kim, M., Lee, Y., Jung, G., Son, B., Lee, J., Kwon, Y. and Park, Y. (2014): Isolation and identification of flavonoids from corn silk. Korean J Crop Sci ;59:435-444.

Ku, K., Kim, S., and Kang, Y. (2009): Antioxidant activity and functional components of corn silk (Zea mays L.) Korean J. Plant Resour ; 22:323-329.

Mallikarjuna, K., Nishanth, K., Reddy, T., Reddy, K. (2008): Amendmenta of antioxidant enzyme status in different skeletal muscle fibers under age induced oxidative stress conditions with reference to exercise training. Asian J Exp Sci; 22:117-128.

Miriam,j.G.,Induja,T.A., Manoj,J.B. and Shivasamy, M.S. (2015): Recent trends in effective utilization of by-product corn,Indain Journal of Science,22(76), 18-26. 


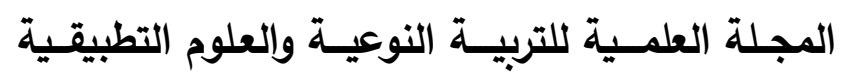

The Scientific Journal of Specific Education and Applied Sciences

Nishikimi, M. , Appaji, N. and Yagi, K. (1972): The occurrence of superoxide anion in the reaction of reduced phenazine methosulphate and molecular oxygen. Biochem. Biophys. Res. Commun.; 46(2): 849-854.

Pham H., He H., and Pham C. (2008): Free radicals, antioxidants in disease and health. Int J Biomed Sci, 4 (2) 89-96.

Seethalakshmi, B., Narasappa, A., and Kenchaveerappa, S. (1982): Protective effect of Ocimum sanctum in experimental liver injury in albino rats. Indian. J. Pharmacol.; (14) : 63-65.

Singh, J., Garg, K., Yadav, M. and Lal, H. (1992): Effect of adenosine and inosine on Carbon tetrachloride induced liver damage in rats. Indian J. Physiol. Pharmacol; 36 (1):39-42.

Snedecor, G. and Cochran, W. (1980): Statistical methods., $7^{\text {th }}$ Ed., Iowa State University Press, Ames, USA (90).

Reeves, P.; Nielsen, F. and Fahmy, G. (1993) : Purified diets for laboratory rodents : Final report of the American Institute of Nutrition writing committee on the reformulation of the AIN- 76 a rodent diet. J. .Nurtr. 123(51): $1939-1951$.

Roy, E., (1970): Colorimetric determination of Co. St Louis. Toronto. Princeton; 1088-1273.

Sherwin, J. (1984): Liver Function. In Kaplan LA,Pesce AJ,eds.Clinical chemistry ,theory,analysis,and correlation.St Louis: Mosby 55(25):420-438.

So, R., Ae W. , Hyun, J, Sun, J., Lim, K., Hyeon, J., Myung, H., and Woo, K. (2017): Corn silk extract improves benign prostatic hyperplasia in experimental rat model. Nutr Res Pract ; 11(5): 373-380.

Sukandar, Y., Sigil, J. and Ferdiana, L. (2013): Study of kidney repair mechanisms of cornsilk (Zea MaysL.Hair Binahong (Anredera cordifolia (Ten) Steenis) Leaves combination in rat model of kidney failure, International Journal of Pharmacology ,ISSN 1811-7775.

Tanideh, N., Zarifi, F., Rafiee, S., Khastkhodaei, M., Hosseinabadi, O., Tarkesh, F., Kherad, Z., Taghi, M., Kamali, M., Shekarkhar, G., Jahromi, M., Zarifi, F., (2018): Effect of methanolic extract of corn silk on cisplatin induced nephrotoxicity in rats. Galen medical journal.7, e1258. 


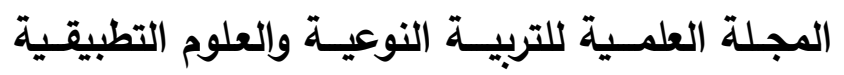

The Scientific Journal of Specific Education and Applied Sciences

Tian, J., Chen, H., Chen, S., Xing, L., Wang, Y., and Wang, J. (2013): Comparative studies on the constituents, antioxidant and anticancer activities of extracts from different varieties of corn silk. Food Funct ;4:1526-1534. doi: 10.1039/c3fo60171d.

Wan, P., Sheng Z., Han, Q., Zhao, Y., Cheng, G. and Li, Y. (2014): Enrichment and purification of total flavonoids from Flospopuli extracts with macroporous resins and evaluation of antioxidant activities in vitro. J. Chromatogr. B, 945: 68-74.

Way, L. and Doherty, G. (2003): Current surgical diagnosis and treatment. 11th ed. St. Louis: McGraw Hill.

Young, D. (1990): Effect of drugs on clinical laboratory tests . Am. J. Clin. Pathol 3(7):6-12.

Young, S. (2001): Effect of diseases on Clinical Lab .Tests $4^{\text {th }}$ ad AACC. 


\section{المجـلة العلمـية للتربيـة النوعيـة والعلوم التطبيقـية}

\section{The Scientific Journal of Specific Education and Applied Sciences}

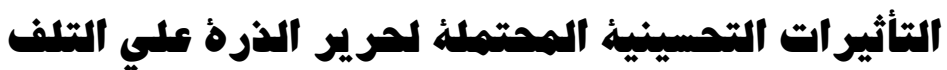

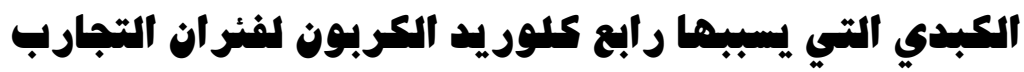

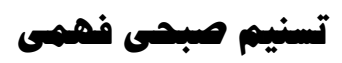

قسم التغذية وعلوم الأطعمة، كلية الاقتصاد المنزلى، جامعة حلوان

تهدف هذه الدراسه الى معرفة التأثيرات التحسينية لحرير الذرة على التلف

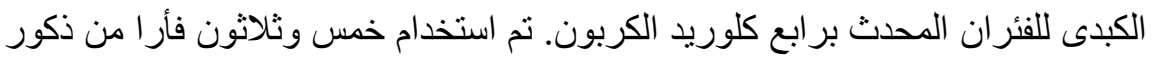

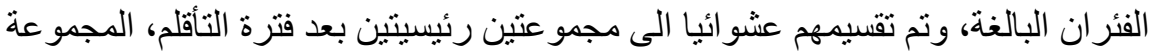
الاولى (العدد V فئر V ان) وتعتبر المجمو عة الضابطة السالبه بينما تم حقن العدد المتبقى

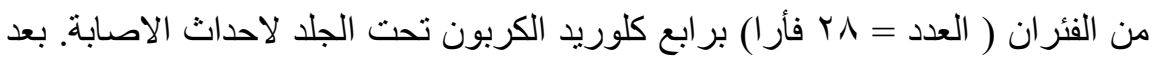

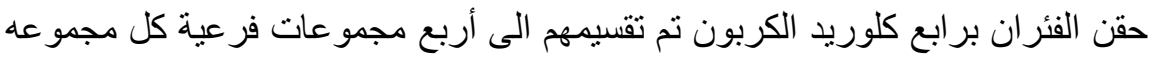

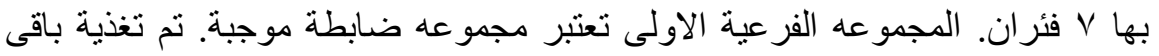

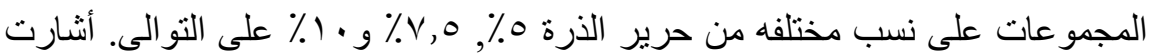

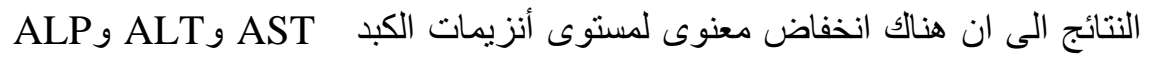
بالإضافة الى مستوى الالبيومين بالسيرم، ومستوى البيليروبن الكلى (البليروبن المباشر و الغير مباثر) مقارنة بالمجموعه الضابطة الموجبة. مستوى يوريا النيتروجين و الكرياتينين انخفض فى جميع المجموعات التى تغذت على حرير الذرة مقارنة بالمجموعه

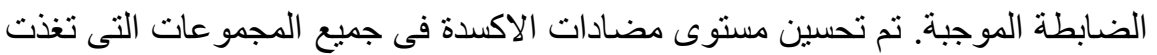
على حرير الذرة مقارنة بالمجموعه الضابطة الموجبة. علاوة على ذللك، مستوى انخفض فى جميع المجمو عات عن المجمو عه الضابطة الموجبة. يمكن أن نستنتج

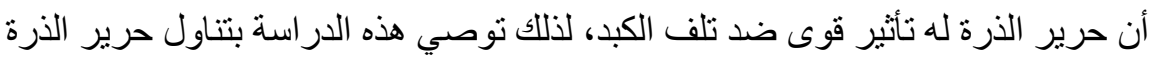
فهو مفيد للمرضى الذين يعانون من تلف الكبد. الكلمات المفتاحية: حرير الذرة، انزيمات الكبد، التلف الكبدى، انزيمات مضادات الاكسدة لكيد 